\title{
Leaf non-structural carbohydrates regulated by plant functional groups and climate: Evidences from a tropical to cold-temperate forest transect
}

\author{
Nani Li, Nianpeng He*, Guirui Yu*, Qiufeng Wang, Jian Sun \\ Key Laboratory of Ecosystem Network Observation and Modeling, Institute of Geographic Sciences and Natural Resources Research, \\ Chinese Academy of Sciences, 100101 Beijing, China
}

\section{A R T I C L E I N F O}

\section{Article history:}

Received 14 June 2015

Received in revised form

13 November 2015

Accepted 16 November 2015

Available online 5 December 2015

\section{Keywords:}

Non-structural carbohydrates

Plant life forms

Sugar

Starch

Forest

Transect

China

\begin{abstract}
A B S T R A C T
Non-structural carbohydrates (NSCs), e.g., glucose and starch, play important roles in metabolic processes of plants and represent important functional traits in plant's adaptation to external environment. To explore the variations in leaf NSCs among species and communities at a large scale and their influencing factors, we investigated the contents of leaf NSCs among 890 plant species in nine typical forests along the north-south transect of eastern China. The results showed that the contents of leaf soluble sugars, starch, and NSCs (sugars + starch) were highly variable among different plant species on the site scale, and their mean values for the 890 plant species were $45.7 \mathrm{mg} \mathrm{g}^{-1}, 47.5 \mathrm{mg} \mathrm{g}^{-1}$, and $93.2 \mathrm{mg} \mathrm{g}^{-1}$, respectively. All three metrics varied markedly across plant functional groups in the order of trees $<$ shrubs $<$ herbs. Weak latitudinal patterns of leaf soluble sugars, starch, and NSCS were observed from tropical to coldtemperate forests at the levels of species and plant functional groups. The contents of leaf soluble sugars, starch, and NSCs decreased with increasing temperature and precipitation which supports the growth limitation hypothesis at a large scale. In trees, leaf soluble sugars, starch, and NSCs increased with increasing photosynthetic active radiation (PAR); and were positively correlated with specific leaf area (SLA). The spatial patterns of leaf NSCs in forests along the north-south transect of eastern China and their relationships with temperature, precipitation, PAR, and SLA illustrate an important adaptation of plant communities to environmental changes at the continental scale.
\end{abstract}

(c) 2015 Elsevier Ltd. All rights reserved.

\section{Introduction}

Carbohydrates are the primary photosynthate and the key energy source of plant metabolism, and therefore play vital roles in plant's life processes (Volenec et al., 1996; Ogren et al., 1997; Ögren, 2000; Bouma, 2005). Carbohydrates in plants are generally classified as structural carbohydrates or non-structural carbohydrates (NSCs) (Li et al., 2002, 2008). The structural carbohydrates, such as lignin and cellulose, are primarily used for the construction of plant structural support tissues or long-term reserves ( $\mathrm{Li}$ et al., 2002; Pan et al., 2002; Yin et al., 2009). NSCs, mainly as glucose and starch, are used in metabolic processes of photosynthesis, respiration, and production (Koch, 1996; van den Ende et al., 1999). The content of NSCs and their composition (ratio of glucose:starch) reflect the balance between carbon sources and sinks in plants (Mooney, 1972; Chapin et al., 1990; Hoch et al., 2003; Würth et al.,

\footnotetext{
* Corresponding authors. Tel.: +86 10 64889263; fax: +86 1064889399

E-mail addresses: henp@igsnrr.ac.cn (N. He),yugr@igsnrr.ac.cn (G. Yu).
}

2005) and indicate the adaptive strategies of plants to changing environments (Trom et al., 1989; Koch, 1996; Loewe et al., 2000). Gough et al. (2009) have demonstrated that, in temperate deciduous forests, $55 \%$ of the annual net carbon assimilation in plant canopy is firstly allocated to labile carbon production (main NSCs) rather than to structural carbon production, where labile carbon produced during late summer supported the structural growth and respiration in dormant season. The content of NSCs and their allocation ratios in leaves, roots, and stems are considered as an eco-physiological attribute to evaluate the carbon budgets and adaptive strategies of plant species (Chapin et al., 1990; Li et al., 2001; Myers and Kitajima, 2007; Poorter and Kitajima, 2007).

Many factors may influence leaf NSCs content (Volaire and Gandoin, 1996; Gaudet et al., 1999; Nanamori et al., 2004). To date, studies on factors influencing leaf NSCs have focused on nutrient elements (Nanamori et al., 2004), temperature (Gaudet et al., 1999; Gough et al., 2010), precipitation (Schellenbaum et al., 1999), and phenology (Gough et al., 2010). Less information is available regarding factors such as light intensity, leaf traits, leaf life forms (e.g., needle-leaf and broad-leaf), and plant functional groups 
(PFGs, trees, shrubs, and herbs). Furthermore, most of the studies related to leaf NSCs have mainly conducted on basis of controlled experiments regarding the responses of leaf NSCs to changing environment, or focused on the variations of leaf NSCs at the individual level, or along altitudinal gradients (Mooney and Billings, 1965; Hoch et al., 2002). To date, it remains unknown the level of variation of leaf NSCs among a large number of plant species at a large scale.

Currently, two bio-physiological hypotheses have been developed from these treeline studies to explain the variation in leaf NSCs with temperature: carbon limitation hypothesis (Schulze et al., 1967; Stevens and Fox, 1991; Wardle, 1993) and direct growth limitation hypothesis (Körner, 1998). According to the carbon limitation hypothesis, leaf NSCs content is expected to decrease with decreasing temperature because of the reduced photosynthetic carbon assimilation (Stevens and Fox, 1991; Wardle, 1993). In contrast, according to the growth limitation hypothesis, if tissue formation is limited with decreasing temperature, the content of leaf NSCs should increase because of the decreased demand for structural carbon with no consideration of the limitation of nitrogen, phosphorus, and others (Körner, 1998). These two hypotheses provide contradictory predictions and have not yet to be verified using the data from forests across the latitudinal transect at a large scale.

Leaf NSCs are mainly composed of soluble sugars and starch. The soluble sugars in leaves are primarily glucose, sucrose, and fructose (Hoch et al., 2003; Würth et al., 2005). The quantity of soluble sugars may increase under conditions of low temperature and drought, because soluble sugars are not only involved in the osmotic adjustment of cells but are also signal substances that enable adaptation to changing environment (Pan et al., 2002). Starch is used as a relatively long-term energy storage in plants (Zhang et al., 2006), and it's storage in leaves is negatively related to photosynthesis (Li et al., 2008). Highly soluble sugars are beneficial for amylolysis, and their accumulation is triggered by extreme day-night temperature differences (Trethewey and Aprees, 1994). Spatial variations in leaf NSCs across multiple climatic zones have been scarcely reported, preventing the testing of the above-mentioned hypotheses in terrestrial ecosystems at a large scale.

The north-south transect of eastern China (NSTEC) as the 15th standard transect of the International Geosphere-Biosphere Programme, covering multiple climatic zones and including almost all forest types except for boreal forest in Northern Hemisphere, provide an ideal setting for investigating the geographical patterns of leaf NSCs at a large scale. Herein, we measured the contents of leaf NSCs in 890 plant species collected from nine typical forests along the NSTEC. The main objectives of the present study were: (1) to investigate the variations in leaf NSCs among species, plant functional groups, and communities at a large geographic scale, (2) to explore the spatial patterns of leaf NSCs (the content of sugars and starch, NSCs, and the allocation ratio of sugar:starch) and their influencing factors (temperature, precipitation, plant functional groups, and others), and (3) to test the above-mentioned hypotheses to better characterize the underlying physiological mechanisms for the variations in leaf NSCs.

\section{Materials and methods}

\subsection{Site description}

Nine typical forests were selected along the $3500 \mathrm{~km}$ north-south transect of eastern China (NSTEC), which is an unique belt of vegetation formed by the heat gradients (Fig. 1) (Zhang and Yang, 1995). The growing season of plants in the north is from approximately April to October, whereas the plants

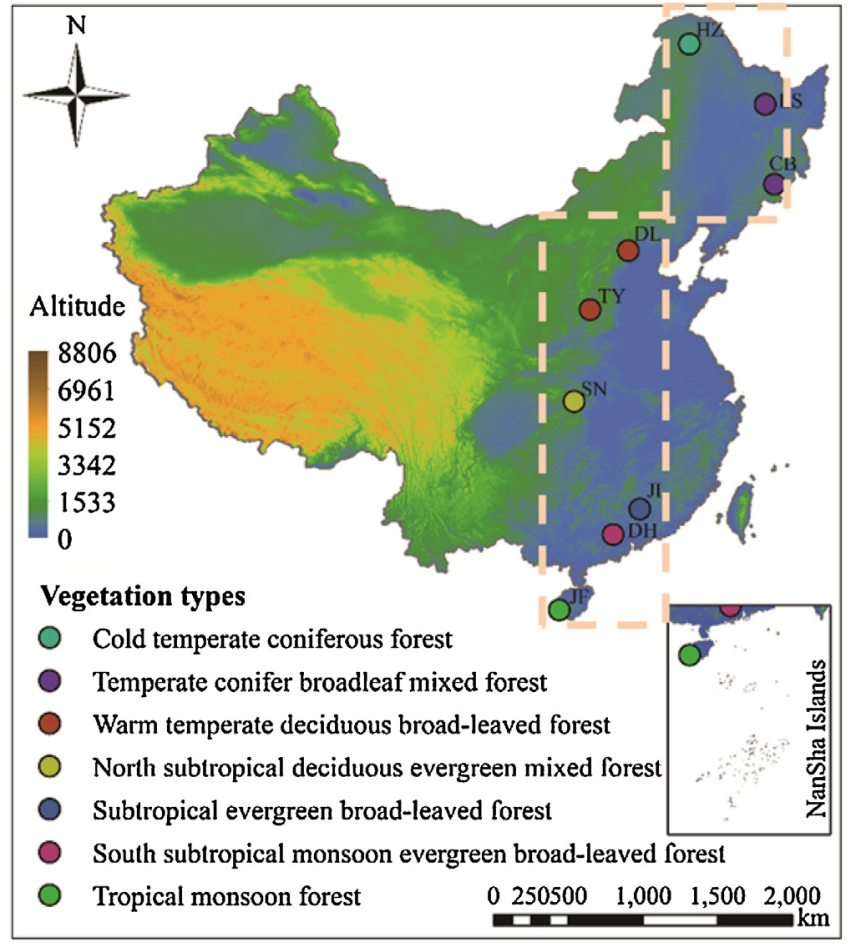

Fig. 1. The selected nine forest ecosystems along the north-south transect of eastern China (NSTEC, yellow frame). JF, Jiangfeng; DH, Dinghu; JL, Jiulian; SN, Shennong; TY, Taiyue; DL, Dongling; CB, Changbai; LS, Liangshui; HZ, Huzhong. (For interpretation of the references to color in this figure legend, the reader is referred to the web version of the article.)

in the south grow year-round. The mean annual temperature at these sites ranges from -3.67 to $23.15^{\circ} \mathrm{C}$, and the mean annual precipitation ranges from 473.0 to $2265.8 \mathrm{~mm}$ (Table 1 ).

The nine forests thus span cold-temperate, temperate, subtropical, and tropical forests. For each forest, field investigations were conducted on plots setup within the national nature reserves of China to avoid strong disturbances (e.g., fire, cutting, or plantation); these nature reserves are strongly representative of each region. Detailed information regarding the selected forests is provided in Table 1.

\subsection{Field sampling}

Field sampling was conducted from July 2013 to August 2013. We randomly set up four plots $(30 \mathrm{~m} \times 40 \mathrm{~m})$ in each selected forest. Firstly, we investigated the community structure of trees, shrubs, and herbs in each plot. Subsequently, we sampled the leaves of trees, shrubs, and herbs in these plots from 10:00 a.m. to 3:00 p.m. For each tree species, we randomly selected healthy and mature trees in each plot and then sampled the leaves from the fully sunlit upper crown using a long chain saw or artificial climbing trees. For each shrub species, we collected the upper leaves; for each herb species, a mixed sample of fresh and healthy leaves was taken. Leaf samples for a given plant species were mixed together in each plot as a replicate. After field sampling, leaf samples were immediately stored in a cool box with ice, and upon transfer to the laboratory, they were minimally cleaned and stored immediately in a refrigerator $\left(-20^{\circ} \mathrm{C}\right)$.

In total, samples of 1112 plant species were collected in the nine forests (four replicates for each species). Since some plant species were present in more than one forests, the collected plant species comprised 890 plant species, 491 genera, and 156 families. Of the 890 plant species sampled, there were 282 tree species, 
Table 1

Selected information for nine forest ecosystems along the north-south transect of eastern China (NSTEC).

\begin{tabular}{|c|c|c|c|c|c|c|c|}
\hline Sampling sites & Longitude (E) & Latitude $(\mathrm{N})$ & $\operatorname{MAT}^{\mathrm{b}}\left({ }^{\circ} \mathrm{C}\right)$ & $\mathrm{MAP}(\mathrm{mm})$ & Vegetation type & Dominant species & Soil type \\
\hline $\mathrm{JF}^{\mathrm{a}}$ & $108^{\circ} 51^{\prime} 26^{\prime \prime}$ & $18^{\circ} 44^{\prime} 18^{\prime \prime}$ & 23.15 & 2265.8 & $\begin{array}{l}\text { Tropical mountain rain } \\
\text { forest }\end{array}$ & $\begin{array}{l}\text { Schoepfia jasminodora Sieb., } \\
\text { Ficus vasculosa Wall., } \\
\text { Madhuca hainanensis Chun. }\end{array}$ & $\begin{array}{l}\text { Lateritic yellow } \\
\text { earth }\end{array}$ \\
\hline DH & $112^{\circ} 32^{\prime} 14^{\prime \prime}$ & $23^{\circ} 10^{\prime} 25^{\prime \prime}$ & 21.83 & 1927 & $\begin{array}{l}\text { South subtropical } \\
\text { evergreen broad-leaved } \\
\text { forest }\end{array}$ & $\begin{array}{l}\text { Schima superba Gardn., } \\
\text { Cryptocarya chinensis } \\
\text { Hemsl., Pinus massoniana } \\
\text { Lamb. }\end{array}$ & Laterite \\
\hline $\mathrm{JL}$ & $114^{\circ} 26^{\prime} 28^{\prime \prime}$ & $24^{\circ} 35^{\prime} 05^{\prime \prime}$ & 18.22 & 1769.93 & $\begin{array}{l}\text { Subtropical evergreen } \\
\text { broad-leaved forest }\end{array}$ & $\begin{array}{l}\text { S. superba Gardn., } \\
\text { Castanopsis fargesii Franch., } \\
\text { Castanopsis carlesii Hayata }\end{array}$ & Red earth \\
\hline SN & $110^{\circ} 29^{\prime} 43^{\prime \prime}$ & $31^{\circ} 19^{\prime} 15^{\prime \prime}$ & 8.50 & 1446.71 & $\begin{array}{l}\text { North subtropical } \\
\text { evergreen deciduous } \\
\text { mixed forest }\end{array}$ & $\begin{array}{l}\text { Fagus engleriana Seemen., } \\
\text { Quercus serrata Thunb., } \\
\text { Cyclobalanopsis oxyodon } \\
\text { Oerst. }\end{array}$ & $\begin{array}{l}\text { Yellow-brown } \\
\text { earth }\end{array}$ \\
\hline TY & $112^{\circ} 04^{\prime} 39^{\prime \prime}$ & $36^{\circ} 41^{\prime} 43^{\prime \prime}$ & 5.98 & 644.38 & $\begin{array}{l}\text { Warm temperate } \\
\text { deciduous and broadleaf } \\
\text { mixed forest }\end{array}$ & $\begin{array}{l}\text { Quercus wutaishanica } \\
\text { Mayr., Pinus tabulaeformis } \\
\text { Carr., Populus davidiana } \\
\text { Dode. }\end{array}$ & Cinnamon soil \\
\hline DL & $115^{\circ} 25^{\prime} 24^{\prime \prime}$ & $39^{\circ} 57^{\prime} 27^{\prime \prime}$ & 6.55 & 539.07 & $\begin{array}{l}\text { Warm temperate } \\
\text { deciduous and broadleaf } \\
\text { mixed forest }\end{array}$ & $\begin{array}{l}\text { P. tabulaeformis Carr., Q. } \\
\text { wutaishanica Mayr., Larix } \\
\text { principis-rupprechtii Mayr. }\end{array}$ & Brown soil \\
\hline $\mathrm{CB}$ & $128^{\circ} 05^{\prime} 27^{\prime \prime}$ & $42^{\circ} 24^{\prime} 16^{\prime \prime}$ & 2.79 & 691.00 & $\begin{array}{l}\text { Temperate conifer } \\
\text { broadleaf mixed forest }\end{array}$ & $\begin{array}{l}\text { Pinus koraiensis Siebold., } \\
\text { Larix gmelinii Rupr., } \\
\text { Quercus mongolica Fisch. }\end{array}$ & Dark brown soil \\
\hline LS & $128^{\circ} 53^{\prime} 51^{\prime \prime}$ & $47^{\circ} 11^{\prime} 06^{\prime \prime}$ & 0.01 & 648.34 & $\begin{array}{l}\text { Temperate conifer } \\
\text { broadleaf mixed forest }\end{array}$ & $\begin{array}{l}\text { P. koraiensis Siebold., } L . \\
\text { gmelinii Rupr., Betula } \\
\text { platyphylla Suk. }\end{array}$ & Dark brown soil \\
\hline $\mathrm{HZ}$ & $123^{\circ} 01^{\prime} 12^{\prime \prime}$ & $51^{\circ} 46^{\prime} 48^{\prime \prime}$ & -3.67 & 472.96 & $\begin{array}{l}\text { Cold temperate coniferous } \\
\text { forest }\end{array}$ & $\begin{array}{l}\text { L. gmelinii Rupr., Pinus } \\
\text { sylvestris L., B. platyphylla } \\
\text { Suk. }\end{array}$ & Gray forest soil \\
\hline
\end{tabular}

a JF, Jiangfeng; DH, Dinghu; JL, Jiulian; SN, Shennong; TY, Taiyue; DL, Dongling; CB, Changbai; LS, Liangshui; HZ, Huzhong.

b MAT, mean annual temperature; MAP, mean annual precipitation.

250 shrub species, and 260 herb species. Among the 282 tree species sampled, 191 were evergreen and 91 were deciduous. Additionally, 13 species were conifers and 269 were broadleaf tree species.
It is necessary to point out that our data and analyses did not account for the influence of forest age, phenology, and season on the contents of leaf NSCs (Cruz and Moreno, 2001; Palacio et al., 2007; Scartazza et al., 2013) because of the economic and human cost of

Table 2

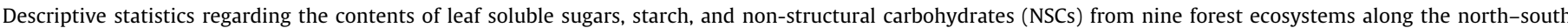
transect of eastern China (NSTEC).

\begin{tabular}{|c|c|c|c|c|c|c|c|c|c|c|c|c|}
\hline Sampling sites & Indicators ( $\mathrm{mg} \mathrm{g}^{-1}$ ) & Min & Max & Mean & Median & SD & $\mathrm{CV}$ & Kurtosis & Skewness & $\mathrm{K}-\mathrm{S} Z^{\mathrm{b}}$ & $P^{\mathrm{b}}$ & $n^{\mathrm{b}}$ \\
\hline \multirow[t]{3}{*}{$\mathrm{JF}^{\mathrm{a}}$} & Soluble sugars & 9.49 & 118.98 & 39.05 & 34.79 & 19.31 & 0.49 & 0.49 & -0.05 & 0.60 & 0.87 & 154 \\
\hline & Starch & 12.81 & 200.41 & 42.87 & 40.53 & 20.88 & 0.49 & 1.22 & 0.13 & 0.63 & 0.82 & 154 \\
\hline & NSCs & 29.28 & 236.94 & 81.92 & 76.85 & 32.08 & 0.39 & 0.59 & 0.21 & 0.46 & 0.99 & 154 \\
\hline \multirow[t]{3}{*}{$\mathrm{DH}$} & Soluble sugars & 5.30 & 106.80 & 33.72 & 27.46 & 20.61 & 0.61 & 0.09 & 0.02 & 0.56 & 0.91 & 172 \\
\hline & Starch & 8.35 & 140.91 & 34.86 & 28.04 & 21.39 & 0.61 & 0.03 & 0.29 & 0.82 & 0.51 & 172 \\
\hline & NSCs & 19.47 & 174.42 & 68.58 & 59.32 & 32.82 & 0.48 & -0.35 & 0.01 & 0.66 & 0.78 & 172 \\
\hline \multirow[t]{3}{*}{$\mathrm{JL}$} & Soluble sugars & 6.48 & 156.93 & 37.56 & 31.33 & 23.07 & 0.61 & 0.23 & -0.11 & 0.52 & 0.95 & 175 \\
\hline & Starch & 11.94 & 162.64 & 34.93 & 32.36 & 17.09 & 0.49 & 0.76 & 0.42 & 0.47 & 0.98 & 175 \\
\hline & NSCs & 22.39 & 203.08 & 72.49 & 65.70 & 30.94 & 0.43 & 0.09 & 0.09 & 0.95 & 0.33 & 175 \\
\hline \multirow[t]{3}{*}{ SN } & Soluble sugars & 7.62 & 162.20 & 43.45 & 38.40 & 24.61 & 0.57 & 0.32 & -0.19 & 0.64 & 0.81 & 138 \\
\hline & Starch & 7.56 & 137.32 & 46.68 & 39.97 & 24.83 & 0.53 & 0.43 & -0.17 & 0.71 & 0.70 & 138 \\
\hline & NSCs & 23.35 & 203.34 & 90.13 & 84.64 & 39.38 & 0.44 & 0.06 & -0.18 & 0.47 & 0.98 & 138 \\
\hline \multirow[t]{3}{*}{ TY } & Soluble sugars & 12.10 & 122.82 & 47.00 & 44.10 & 22.23 & 0.47 & -0.18 & -0.18 & 0.60 & 0.86 & 82 \\
\hline & Starch & 17.84 & 104.09 & 49.53 & 45.60 & 18.89 & 0.38 & -0.34 & -0.09 & 0.38 & 0.99 & 82 \\
\hline & NSCs & 33.91 & 203.99 & 96.52 & 92.19 & 33.15 & 0.34 & -0.05 & -0.20 & 0.60 & 0.86 & 82 \\
\hline \multirow[t]{3}{*}{ DL } & Soluble sugars & 13.87 & 169.99 & 52.92 & 50.86 & 25.26 & 0.48 & 0.52 & -0.26 & 0.83 & 0.50 & 80 \\
\hline & Starch & 13.06 & 134.40 & 48.95 & 48.93 & 24.98 & 0.51 & -0.67 & -0.28 & 1.14 & 0.15 & 80 \\
\hline & NSCs & 35.74 & 222.94 & 101.87 & 98.54 & 36.68 & 0.36 & 0.22 & -0.39 & 0.50 & 0.96 & 80 \\
\hline \multirow[t]{3}{*}{$\mathrm{CB}$} & Soluble sugars & 16.42 & 210.63 & 77.80 & 71.26 & 44.02 & 0.57 & -0.44 & -0.43 & 0.81 & 0.53 & 114 \\
\hline & Starch & 7.39 & 201.82 & 75.93 & 68.26 & 42.11 & 0.55 & 0.66 & -0.63 & 0.78 & 0.58 & 114 \\
\hline & NSCs & 32.45 & 337.51 & 153.72 & 141.74 & 72.19 & 0.47 & -0.39 & -0.38 & 0.78 & 0.58 & 114 \\
\hline \multirow[t]{3}{*}{ LS } & Soluble sugars & 13.97 & 141.57 & 56.25 & 49.56 & 27.34 & 0.49 & -0.32 & -0.27 & 0.55 & 0.4 & 105 \\
\hline & Starch & 12.68 & 225.55 & 65.07 & 60.48 & 32.23 & 0.50 & 1.30 & -0.36 & 0.87 & 0.43 & 105 \\
\hline & NSCs & 33.69 & 301.75 & 121.32 & 119.36 & 48.97 & 0.40 & 0.11 & -0.20 & 0.68 & 0.75 & 105 \\
\hline \multirow[t]{3}{*}{$\mathrm{HZ}$} & Soluble sugars & 13.52 & 218.45 & 55.31 & 49.85 & 31.35 & 0.57 & -0.32 & -0.14 & 0.91 & 0.37 & 92 \\
\hline & Starch & 8.46 & 161.27 & 55.83 & 46.14 & 34.63 & 0.62 & -0.23 & -0.17 & 0.48 & 0.97 & 92 \\
\hline & NSCs & 33.80 & 379.72 & 111.14 & 102.59 & 58.15 & 0.52 & -0.47 & 0.02 & 0.65 & 0.79 & 92 \\
\hline
\end{tabular}

\footnotetext{
a JF, Jiangfeng; DH, Dinghu; JL, Jiulian; SN, Shennong; TY, Taiyue; DL, Dongling; CB, Changbai; LS, Liangshui; HZ, Huzhong.
}

b K-S Z, Kolmogorov-Smirnov Z; $P, P$-value for the Kolmogorov-Smirnov test; $n$, number of plant species. 
repeated investigations on all of these factors at a large scale. Therefore, since leaf collection was conducted during the peak growing season for each forest we minimized the influences of phenology and seasonal differences on the content of leaf NSCs.

\subsection{Measurements}

We used the standard anthrone colorimetric method to measure the content of leaf NSCs, given its advantage for rapid analysis of large samples (Dubois et al., 1956; Hewitt, 1958; Kabeya and Sakai, 2003). Specifically, for each sampling, $0.2 \mathrm{~g}$ of fresh cut leaves was placed into a $20-\mathrm{ml}$ test tube and mixed with distilled water. The samples were then boiled twice for $30 \mathrm{~min}$ in distilled water to extract the soluble sugars. Filtration of each sample followed by dilution with distilled water yielded a final soluble sugar solution. Subsequently, the solid residues from the filtrate were transferred into a 50 - $\mathrm{ml}$ flask and boiled with $15 \mathrm{ml}$ of distilled water for $15 \mathrm{~min}$. After cooling to room temperature, $2 \mathrm{ml}$ of $9.2 \mathrm{M} \mathrm{HClO}_{4}$ was added to hydrolyze the starch in the residue. After $15 \mathrm{~min}$, the solution was filtered with distilled water to obtain the final starch solution. Sugar and starch concentrations in this solution were determined from the absorbance of the solutions measured at $630 \mathrm{~nm}$ using a UV-vis spectrophotometer (UV-1700, Shimadzu Crop., Suzhou, China). The concentrations of soluble sugars and starch were then transformed to dry matter ratio $\left(\mathrm{mg} \mathrm{g}^{-1}\right)$ using leaf water content (Wang et al., 2015).

\subsection{Other data collected or measured}

Meteorological data (temperature, precipitation, and photosynthetic active radiation [PAR]) were obtained from the long-term monitoring data collected from 722 meteorological stations in China from 1961 to 2010 by spatial interpolation incorporating elevation and topography (Gao et al., 2013). Considering that the leaf samples were collected during the growing season, we also used the warm index as a climatic factor $(\mathrm{Xu}, 1985)$ to discuss the influence of climate on leaf NSCs. The warm index is a seasonal mean temperature, where the season is defined by the number of months with a monthly mean temperature above $5^{\circ} \mathrm{C}$.

Furthermore, specific leaf area (SLA) was measured simultaneously with the measurements of NSCs. In practice, we randomly selected 10 fresh leaves from each plant species and scanned them using a scanner (CanoScan LiDE 110, Canon, Tokyo, Japan); leaf area was measured using Photoshop CS (Adobe Systems, San Jose, CA, USA). The leaves were oven-dried at $70^{\circ} \mathrm{C}$ for $48 \mathrm{~h}$ and then weighed to calculate SLA ( $\mathrm{m}^{2} \mathrm{~kg}^{-1}$ ) (Wang et al., 2015).

\subsection{Data analysis}

The contents of soluble sugars, starch, and NSCs, as well as the sugar:starch ratio, were expressed on a mass basis $\left(\mathrm{mg} \mathrm{g}^{-1}\right)$. NSCs
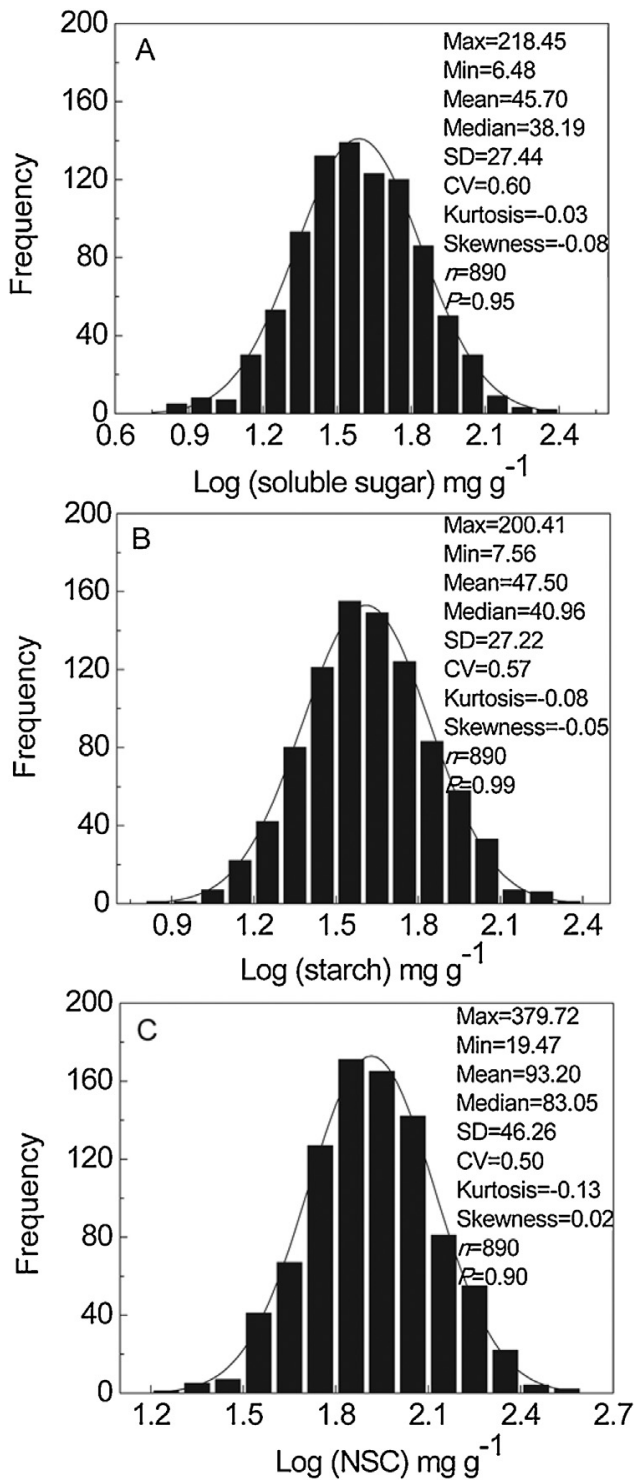

Fig. 2. Histograms of leaf soluble sugars (A), starch (B), and non-structural carbohydrates (C, NSCs) contents in nine forests along the north-south transect of eastern China. Histogram values are $\log _{10}$-transformed, and statistics are shown as untransformed values.

were defined as the sum of soluble sugars and starch (NSCs = soluble sugars + starch). To further compare leaf NSCs content among different plant functional groups, we classified plant species into trees, shrubs, and herbs (Han et al., 2005), with further classification of the

Table 3

Variations in the contents of leaf soluble sugars, starch, and non-structural carbohydrates (NSCs) among plant functional groups in nine forest ecosystems.

\begin{tabular}{|c|c|c|c|c|c|c|c|c|c|}
\hline \multirow[t]{2}{*}{ Functional groups } & \multirow[t]{2}{*}{$n$} & \multicolumn{2}{|c|}{ Soluble sugars $\left(\mathrm{mg} \mathrm{g}^{-1}\right)$} & \multicolumn{2}{|c|}{ Starch $\left(\mathrm{mg} \mathrm{g}^{-1}\right)$} & \multicolumn{2}{|c|}{ NSCs $\left(\mathrm{mg} \mathrm{g}^{-1}\right)$} & \multirow[t]{2}{*}{$r^{\mathrm{a}}$} & \multirow[t]{2}{*}{$P^{b}$} \\
\hline & & Average & SD & Average & SD & Average & SD & & \\
\hline Herb & 260 & 49.89 & 32.69 & 60.12 & 34.58 & 110.00 & 56.94 & 0.45 & $<0.001$ \\
\hline Shrub & 250 & 45.15 & 25.43 & 44.90 & 22.47 & 90.05 & 39.77 & 0.43 & $<0.001$ \\
\hline Tree & 282 & 43.63 & 25.00 & 40.19 & 20.10 & 83.81 & 38.22 & 0.42 & $<0.001$ \\
\hline Evergreen tree & 191 & 37.80 & 18.39 & 37.06 & 16.71 & 74.86 & 28.10 & 0.31 & $<0.001$ \\
\hline Deciduous tree & 91 & 55.85 & 31.84 & 46.76 & 24.66 & 102.62 & 48.65 & 0.54 & $<0.001$ \\
\hline Conifer tree & 13 & 62.88 & 27.43 & 40.51 & 19.19 & 103.39 & 41.69 & 0.53 & 0.06 \\
\hline Broad leaf tree & 269 & 42.69 & 24.55 & 40.18 & 20.18 & 82.87 & 37.87 & 0.42 & $<0.001$ \\
\hline Total & 890 & 45.70 & 27.44 & 47.50 & 27.22 & 93.20 & 46.26 & 0.44 & $<0.001$ \\
\hline
\end{tabular}

a Spearman's rank correlation coefficient $(r)$ between soluble sugars and starch content of leaves ( $n$, number of species).

b $P$, test value. 

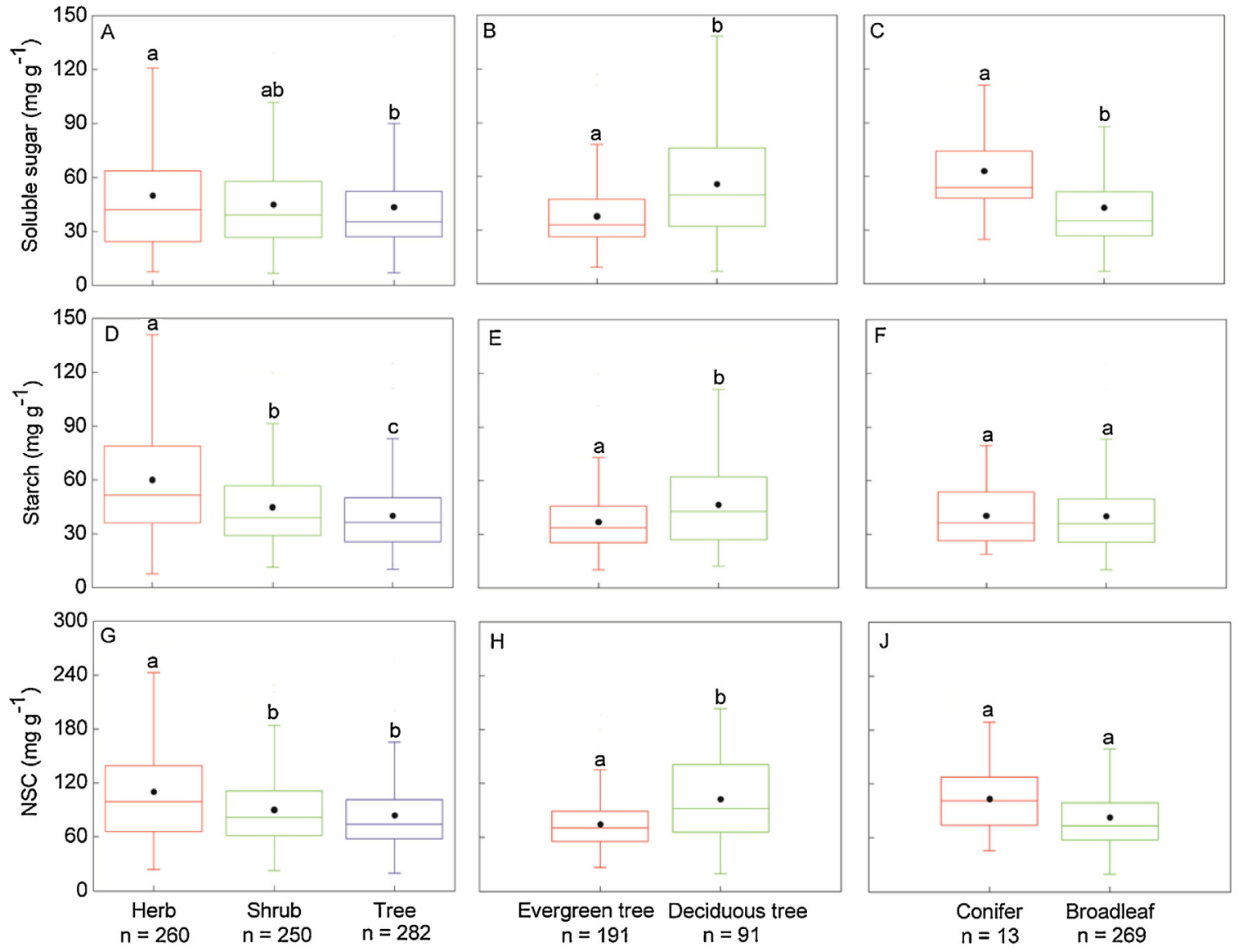

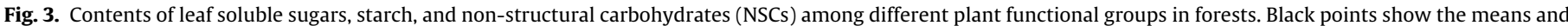
bars represent the standard deviation.

tree species into evergreen and deciduous trees, and into conifers and broadleaf trees.

The data for the contents of soluble sugars, starch, and NSCs were first $\log _{10}$-transformed for normality testing. Then, the untransformed data of soluble sugars, starch, and NSCs were compared among different plant functional groups (PFGs) using one-way analysis of variance with least significant difference test. To determine whether soluble sugars and starch are correlated, we calculated Spearman's rank correlation coefficients across all 890 plant species, and across plant functional groups. Furthermore, we used the regression analyses to explore the latitudinal patterns of leaf NSCs, and determined the best-fitting regression models using the Akaike information criterion. We used temperature (mean of July and August), precipitation (mean of July and August), WI, PAR, and SLA to explore the factors of NSCs. Statistical analyses were conducted using SPSS ver. 11.0 (IBM Corp., Armonk, NY, USA) and figures were produced using Origin ver. 8.0 (OriginLab Corp., Northampton, MA, USA). Significant differences were defined at $P=0.05$ level

\section{Results}

\subsection{Variation in leaf NSCs contents across plant species}

The contents of soluble sugars, starch, and NSCs in leaves were log-normally distributed across all 890 plant species (Fig. 2; Table 2). The contents of soluble sugars, starch, and NSCs exhibited large variations at the species level. In detail, the soluble sugars content ranged from 6.48 to $218.45 \mathrm{mg} \mathrm{g}^{-1}$ with a mean of $45.70 \mathrm{mg} \mathrm{g}^{-1}$, the starch content ranged from 7.56 to $200.41 \mathrm{mg} \mathrm{g}^{-1}$ with a mean of $47.50 \mathrm{mg} \mathrm{g}^{-1}$, and the NSCs content ranged from 19.47 to $379.72 \mathrm{mg} \mathrm{g}^{-1}$ with a mean of $93.20 \mathrm{mg} \mathrm{g}^{-1}$ (Fig. 2). The coefficients of variation (CV) of the soluble sugars, starch, and NSCs contents across all species were $0.60,0.57$, and 0.50 , respectively.

\subsection{Variation in leaf NSCs content across different PFGs}

The contents of soluble sugars, starch, and NSCs in leaves varied markedly among different PFGs (Table 3; Fig. 3); they were highest in herbs, followed by shrubs and then trees for all three parameters

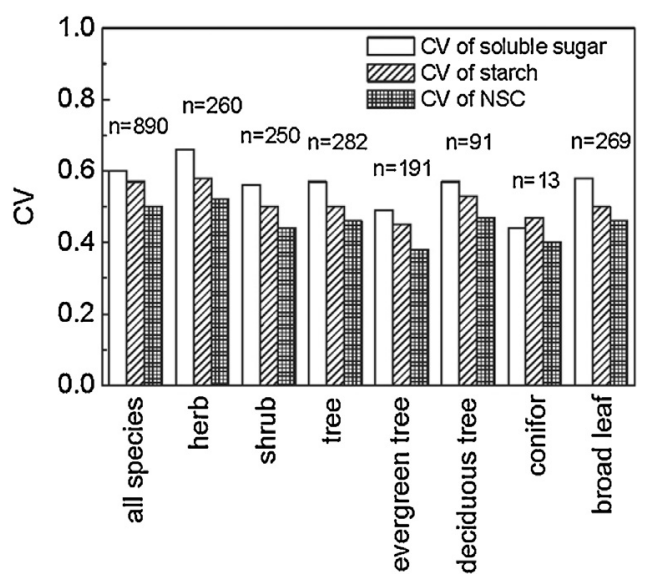

Fig. 4. Coefficient of variation (CV, \%) for leaf soluble sugars, starch, and nonstructural carbohydrates (NSCs) among different plant functional groups. 


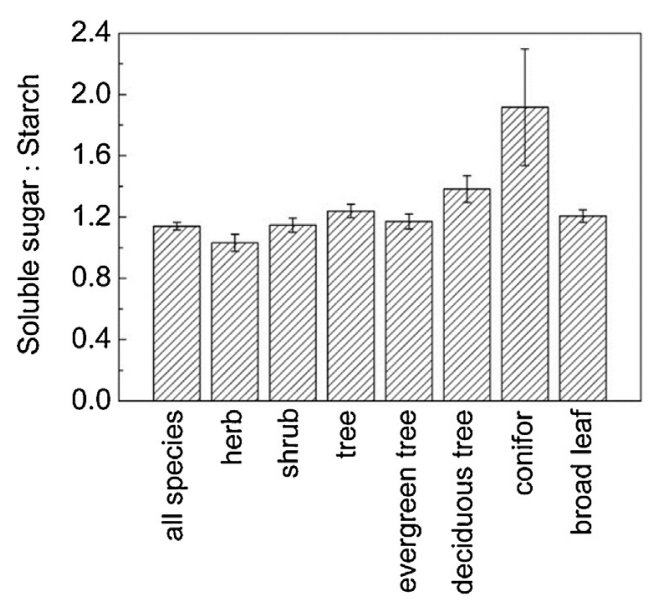

Fig. 5. Changes in sugar:starch ratio among different plant functional groups.

(Table S1). For trees, the contents of soluble sugars, starch, and NSCs were higher in deciduous trees than in evergreen trees and were higher in conifers than in broadleaf trees (Table 3; Fig. 3). Among different PFGs, the coefficient of variation of NSCs was smaller than those of starch and soluble sugars (Fig. 4), indicating a close relationship between starch and soluble sugars in leaves.

Spearman's rank correlation coefficients between leaf soluble sugars and starch showed a significant correlation for each PFGs (all
$P$ 's $<0.001)$, except in conifers $(P>0.05)$ (Table 3$)$. The sugar:starch ratio ranged from 0.99 to 1.42 in the nine forests, which was higher in trees and shrubs than in herbs (Fig. 5). Unexpectedly, the sugar:starch ratio was not significantly correlated with latitude, longitude, temperature, or precipitation, irrespective of statistical scales (data not shown).

\subsection{Spatial patterns of leaf NSCs along the transect}

Spatial patterns related to both latitude and longitude were observed for leaf soluble sugars, starch, and NSCs at the levels of species and PFGs (Fig. 6; Table S2). The contents of soluble sugars, starch, and NSCs were significantly correlated with both latitude and longitude (all $P$ 's $<0.05$, but lower values of $R^{2}$ ) (Fig. 6). Specifically, all three metrics increased with increasing latitude and longitude.

\subsection{Relationships between leaf NSCs content and climatic factors}

The contents of soluble sugars, starch, and NSCs in leaves were negatively correlated with the mean temperature and precipitation of July and August at the levels of species, PFGs (except in conifers) (all P's <0.05) (Fig. 7; Table S3). The contents of soluble sugars, starch, and NSCs were significantly and negatively correlated with warm index $(P<0.05)$ (Fig. 8; Table S4). The contents of leaf soluble sugars, starch, and NSCs in tree species increased
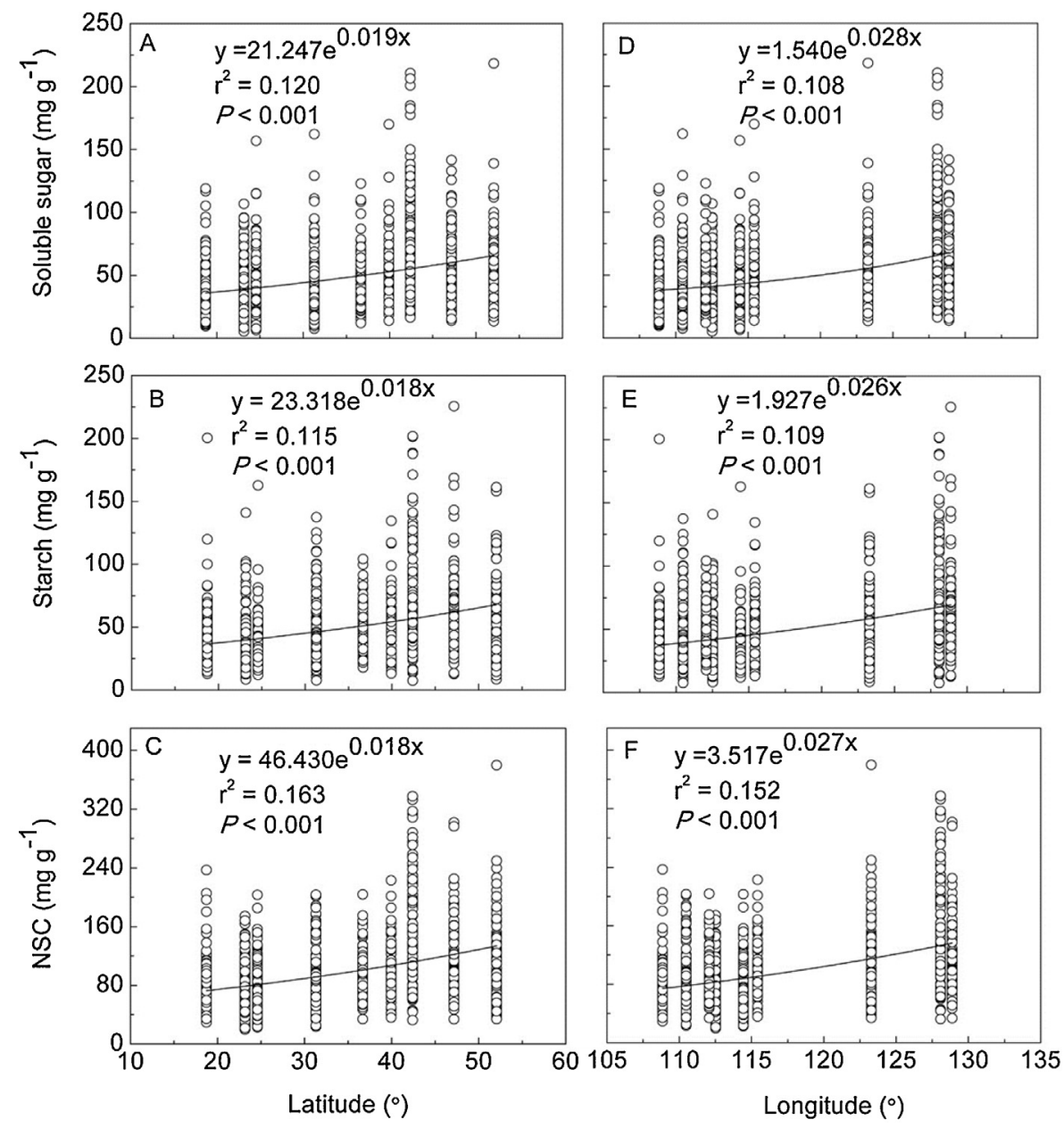

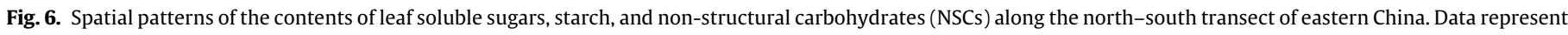
the mean for each species (see details in the Supplementary data file). 

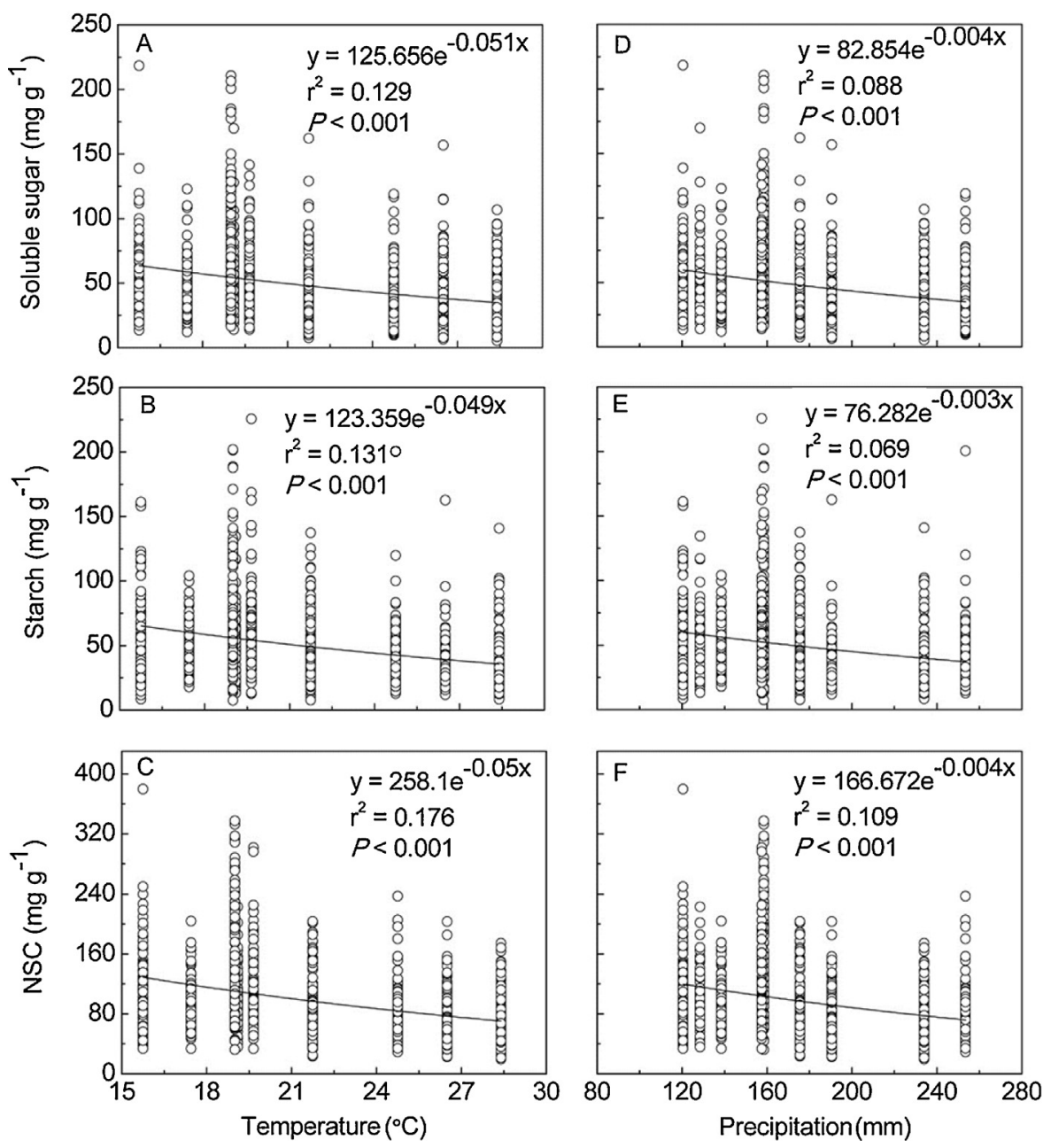

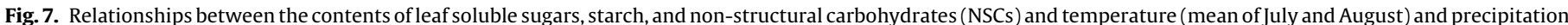
(mean of July and August). Data represent the average for each species (see details in the Supplementary data file).

with increasing PAR (Fig. 9); and also with increasing SLA $(P<0.05)$ (Fig. 10).

\section{Discussion}

\subsection{The variation of leaf NSCs in forests}

The average contents of leaf soluble sugars, starch, and NSCs of the 890 species were $45.70 \mathrm{mg} \mathrm{g}^{-1}, 47.50 \mathrm{mg} \mathrm{g}^{-1}$, and $93.20 \mathrm{mg} \mathrm{g}^{-1}$, respectively, with high variation among different plant species. These data corroborate Würth et al. (2005) who reported leaf NSC content of $60-70 \mathrm{mg} \mathrm{g}^{-1}$ in 17 dominant plant species in tropical forests and Hoch et al. (2003) who reported the contents of leaf NSCs of $137.5 \mathrm{mg} \mathrm{g}^{-1}$ for the 10 dominant plant species in temperate forests. However, direct comparison of the data reported in the previous studies and in the present study is not unambiguous because of the apparent differences in scale and species number in different studies. The higher content of leaf NSCs in herbs compared to shrubs and trees is possibly due to higher $\mathrm{N}$ and $\mathrm{P}$ content (Han et al., 2005; Yin et al., 2009) or due to the lack of structural mass and carbon storage sources in herbs that required for reproduction or longevity. Furthermore, we found that the contents of leaf NSCs was higher in deciduous trees than in evergreen trees, because short-lived, fast-growing species tend to have a higher NSCs content than long-lived, slow-growing species. These findings were in line with previous stoichiometric studies that found that leaves in short-lived, fast-growing species had higher $\mathrm{N}$ and $\mathrm{P}$ content with higher photosynthetic capability (Thompson et al., 1997; Gusewell, 2004); and these deciduous trees stored more NSCs in their leaves before autumn to supply energy for stem or root tissues through the winter (Würth et al., 2005; Gough et al., 2010). The leaf NSCs content in conifers was higher than in broadleaf trees (Table 3; Fig. 3), which was in agreement with the findings of Hoch et al. (2003).

\subsection{Spatial patterns of leaf NSCs and its main influencing factors}

The contents of leaf soluble sugars, starch, and NSCs showed a weak spatial pattern with latitude at the levels of plant species and PFGs. At the species level, the contents of leaf soluble sugars, starch, and NSCs increased with increasing latitude. At the level of PFGs, similar spatial patterns were also observed. Our findings indicate that the spatial patterns of leaf NSCs depend on changes in plant functional groups along the NSTEC. Importantly, the NSCs content, as a plant functional trait, provides valuable information for studies of the leaf economic spectrum because it reflects a mixture of direct and indirect causal relationships between traits (Wright et al., 2004).

Temperature and precipitation exert a strong effect on the contents of leaf NSCs (Stevens and Fox, 1991; Volenec et al., 1996; Grace et al., 2002). In our study, the contents of leaf soluble sugars, starch, and NSCs were negatively correlated with the temperature in July and August. Körner (2003) found that the contents of leaf NSCs in pines decreased as temperature increased from temperate to tropical zones. Our findings extend these conclusions 

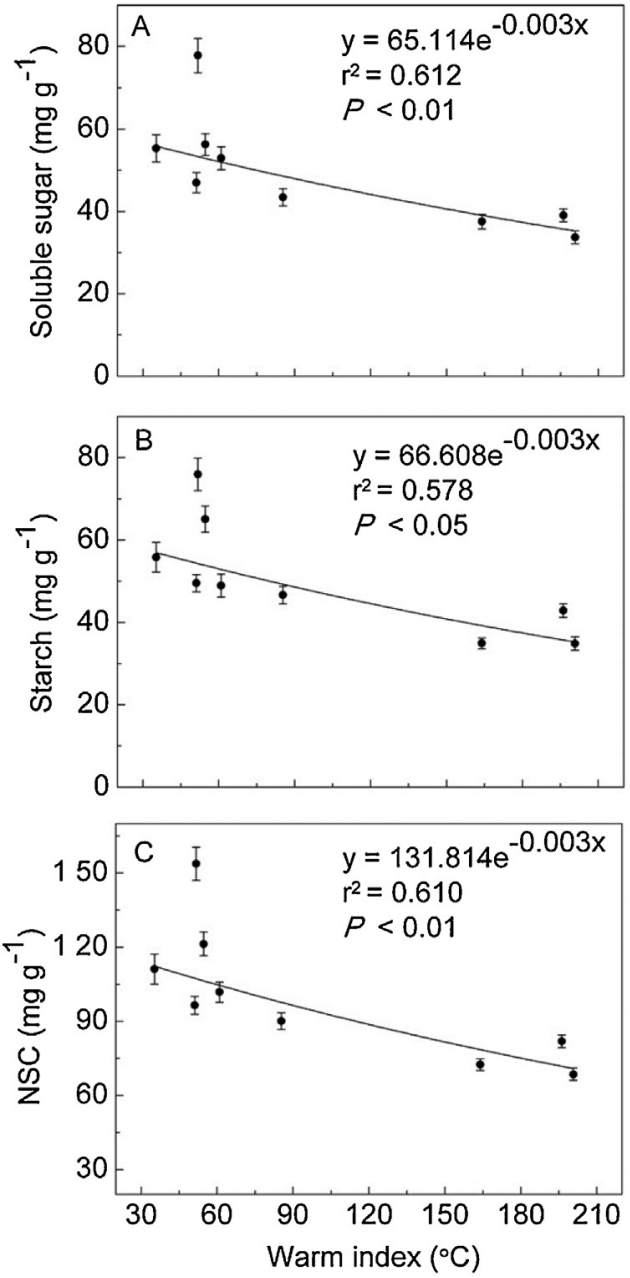

Fig. 8. Relationships between the contents of leaf soluble sugars, starch, and nonstructural carbohydrates (NSCs) and warm index. Data represent the mean and standard error for all plant species in each forest.

across many species and plant functional groups, as well as in environments ranging from cold temperate to tropical forests. These findings provide a tentative support for the growth limitation hypothesis in forests at a large geographical scale (Körner, 1998). Low temperature appeared to directly limit the carbon sink activity and restricted the growth of structural tissues. Essentially, structural carbon demand was reduced in favor of NSCs accumulation in leaves because the physiological processes governing the formation of new tissue were more sensitive to low temperatures than the physiological processes governing photosynthesis (Hoch and Körner, 2003; Körner, 1998; Li et al., 2008).

In temperate and tropical forests, drought stress may affect plant growth more than photosynthesis, resulting in the accumulation of leaf NSCs (Guehl et al., 1993). Würth et al. (2005) found that leaf NSCs content in 17 tropical plant species was higher in the dry season than in the wet season, and Tissue and Wright (1995) reported similar results. Moreover, previous studies demonstrated that drought stress facilitated the accumulation of leaf NSCs (Bacelar et al., 2006; Newell et al., 2002), perhaps because drought stress restricted the structural utilization of carbon (Mooney and Billings, 1965; Tissue and Wright, 1995) but had less effect on photosynthesis (Bryant et al., 1983). Our results confirmed these findings, indicating that the contents of leaf soluble sugars, starch, and NSCs increased with the decrease in the mean precipitation level in July and August across a wide range of forest types and climates. The accumulation of leaf NSCs thus appears to be an adaptive
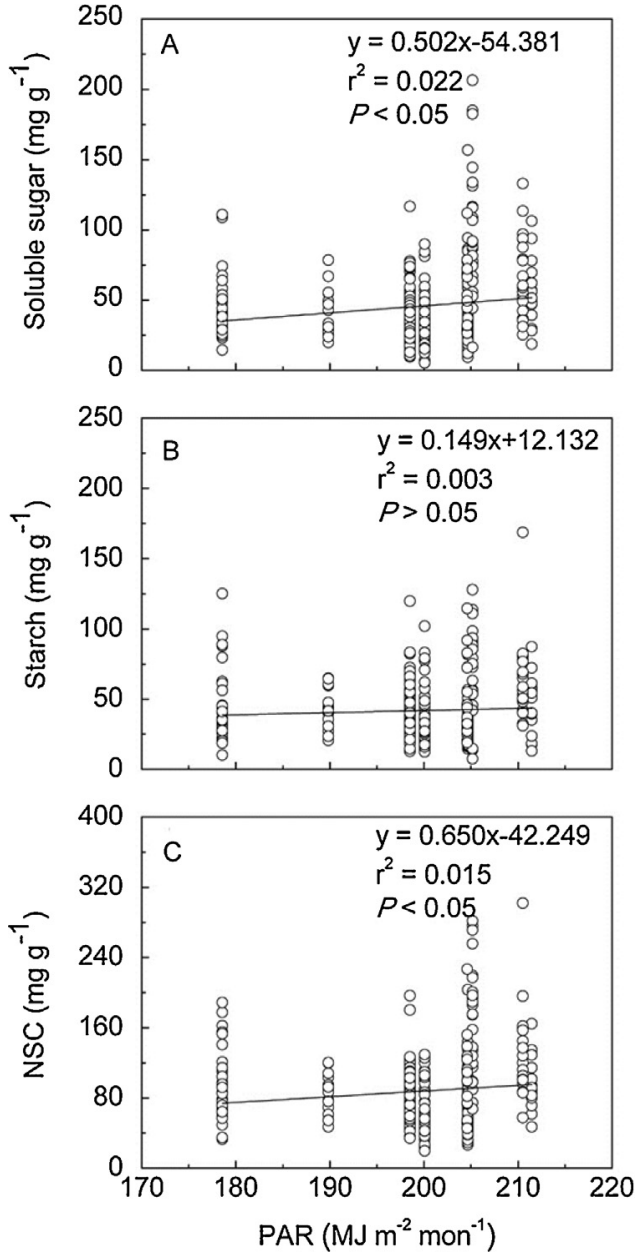

Fig. 9. Relationships between the contents of leaf soluble sugars, starch, and nonstructural carbohydrates (NSCs) in trees and photosynthetic active radiation (PAR, mean of July and August). Data represent the mean for tree species within each forest (see details in the Supplementary data file).

strategy for plants to survive drought and changing temperature (Poorter and Kitajima, 2007; Sala et al., 2012), or to buffer plant during periods when the utilization of NSCs exceeds the uptake (Würth et al., 2005).

The zonal distribution of PAR has an apparent impact on leaf NSCs content by regulating photosynthesis and vegetation distribution at a large geographical scale. The contents of soluble sugars, starch, and NSCs in tree leaves increased with increasing PAR along the NSTEC. The contents of soluble sugars and NSCs were positively correlated with PAR $(P<0.05)$, but a similar correlation was not observed for starch, possibly because starch was mainly stored as energy and therefore was affected less by PAR. Furthermore, SLA is a key leaf trait and reflects the strategy of plant carbon absorption. A higher SLA is usually associated with a higher light capture area of leaves and a higher net photosynthetic rate (Wright et al., 2002). Therefore, the observed increases in soluble sugars, starch, and NSCs with increasing SLA possibly resulted from higher photosynthetic rates. It is therefore necessary to consider additional factors, such as phylogenetic relationships, climate, soil, leaf morphological traits, element composition, and others to further explore the factors determining leaf NSCs at large scale in the future.

\subsection{Allocation strategies of leaf NSCs in forests}

The soluble sugar content may increase under conditions of low temperature and drought because soluble sugars are not only 

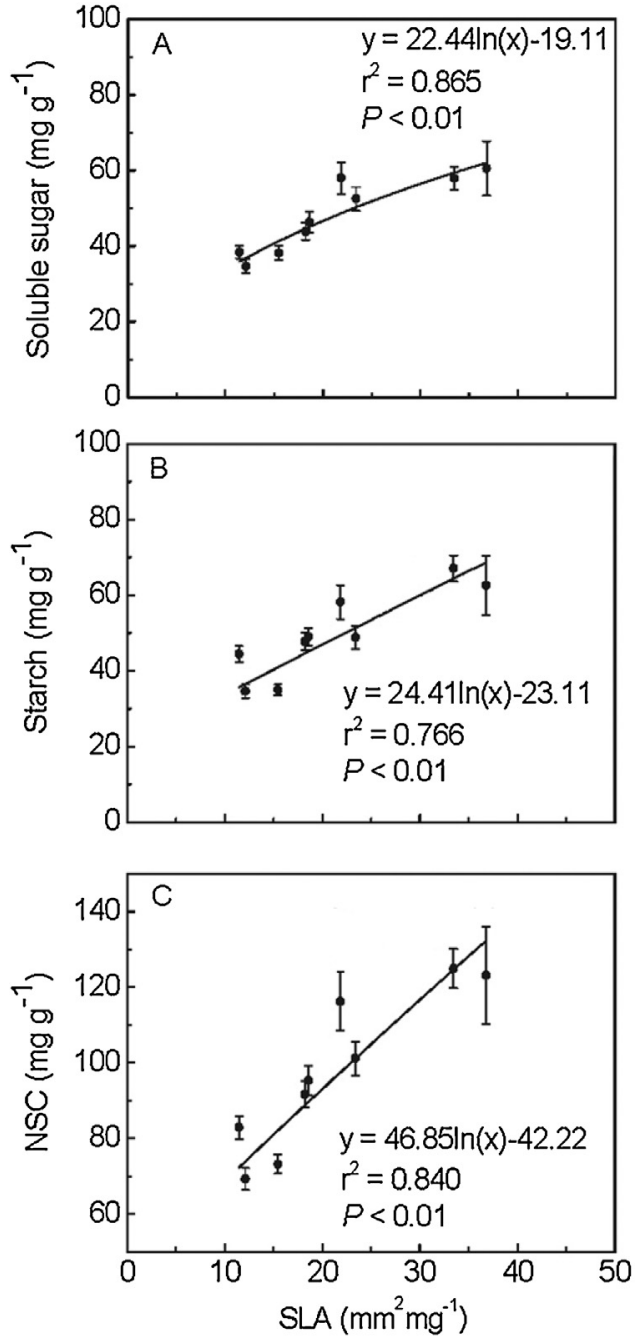

Fig. 10. Relationships between the contents of leaf soluble sugars, starch, and nonstructural carbohydrates (NSCs) and specific leaf area (SLA). Data represent the means and standard error.

involved in the osmotic adjustment of cells but also serve as signal substances to enable adaptation to environmental changes. Starch has little effect on osmolality but has benefits for long-term energy storage in plants (Yan et al., 2014). The proportion of soluble sugars and starch in plants (i.e., the sugar:starch ratio) should thus reflect the response to environmental changes, and should be regulated by phenology or seasonality (Li et al., 2008; Gough et al., 2010). Possibly for this reason, some studies have found higher sugar:starch ratios in plants subjected to lower temperatures (Strand et al., 2003; Patton et al., 2007). These differences between the previous and current studies may be attributed to the higher temperature in sampled forests in this study, compared to those measured in Himalayan trees reported by Li et al. (2008); this higher temperature is expected to shift the allocation balance from soluble sugars toward starch, as discussed above. Additionally, the number of plant species was different. Li et al. (2008) reported a relatively narrow set of species. However, in this study, the expected relationship between leaf sugar:starch ratio and temperature was not observed across the transect. It is possible that the sugar:starch ratio could be amplified at very low temperatures, such as in the Himalayas, but decreased in more temperate and tropical forests. For example, we found that the sugar:starch ratio in tree leaves was higher than that of herbs, possibly because herbs may experience a higher demand for soluble sugars than woody plants, or because woody plants tend to invest more in long-term energy storage than herbs.

In summary, the contents of soluble sugars, starch, and NSCs varied among plant species in Chinese forests, with the mean of $45.70 \mathrm{mg} \mathrm{g}^{-1}, 47.50 \mathrm{mg} \mathrm{g}^{-1}$, and $93.20 \mathrm{mg} \mathrm{g}^{-1}$, respectively. There is a weak latitudinal pattern of leaf soluble sugars, starch, and NSCs from tropical to cold-temperate forests at the levels of species and PFGs. The contents of leaf soluble sugars, starch, and NSCs decreased with increasing temperature, precipitation, and warm index, thus supporting the growth limitation hypothesis. Furthermore, the sugar:starch ratio was not correlated with temperature or precipitation. These findings provide new insights into the underlying mechanisms driving NSCs allocation at a large geographical scale, with implications for the adaptability of plant species to climate change scenarios.

\section{Acknowledgements}

This work was partially supported by the Major Program of the National Nature Science Foundation of China (31290221, 31570471), and the Program for "Kezhen" Distinguished Talents in Institute of Geographic Sciences and Natural Resources Research, CAS (2013RC102).

\section{Appendix A. Supplementary data}

Supplementary data associated with this article can be found, in the online version, at http://dx.doi.org/10.1016/j.ecolind.2015. 11.017 .

\section{References}

Bacelar, E.A., Santos, D.L., Moutinho-Pereira, J.M., Goncalves, B.C., Ferreira, H.F., Correia, C.M., 2006. Immediate responses and adaptative strategies of three olive cultivars under contrasting water availability regimes: changes on structure and chemical composition of foliage and oxidative damage. Plant Sci. 170, 596-605.

Bouma, T.J., 2005. Understanding plant respiration: separating respiratory components versus a process-based approach. In: Plant Respiration. Springer, pp. 177-194.

Bryant, J.P., Chapin, F.S., Klein, D.R., 1983. Carbon nutrient balance of boreal plants in relation to vertebrate herbivory. Oikos 40, 357-368.

Chapin, F.S., Schulze, E.-D., Mooney, H.A., 1990. The ecology and economics of storage in plants. Annu. Rev. Ecol. Systemat., 423-447.

Cruz, A., Moreno, J.M., 2001. Seasonal course of total non-structural carbohydrates in the lignotuberous Mediterranean-type shrub Erica australis. Oecologia 128, 343-350.

Dubois, M., Gilles, K.A., Hamilton, J.K., Rebers, P.A., Smith, F., 1956. Colorimetric method for determination of sugars and related substances. Anal. Chem. 28, 350-356.

Gao, Y.Z., He, H.L., Zhang, Q.Q., Lu, G.R., Yu, G.R., Zhang, Z.I., 2013. Spatio-temporal variation characteristics of surface net radiation in China over the past 50 years. J. Geo-Inf. Sci. 15, 1-10.

Gaudet, D.A., Laroche, A., Yoshida, M., 1999. Low temperature-wheat-fungal interactions: a carbohydrate connection. Physiol. Plant. 106, 437-444.

Gough, C.M., Flower, C.E., Vogel, C.S., Dragoni, D., Curtis, P.S., 2009. Whole-ecosystem labile carbon production in a north temperate deciduous forest. Agric. For. Meteorol. 149, 1531-1540.

Gough, C.M., Flower, C.E., Vogel, C.S., Curtis, P.S., 2010. Phenological and temperature controls on the temporal non-structural carbohydrate dynamics of Populus grandidentata and Quercus rubra. Forests 1, 65-81.

Grace, J., Berninger, F., Nagy, L., 2002. Impacts of climate change on the tree line. Ann. Bot. 90, 537-544.

Guehl, J., Clement, A., Kaushal, P., Aussenac, G., 1993. Planting stress, water status and non-structural carbohydrate concentrations in Corsican pine seedlings. Tree Physiol. 12, 173-183.

Gusewell, S., 2004. N:P ratios in terrestrial plants: variation and functional significance. New Phytol. 164, 243-266.

Han, W., Fang, J., Guo, D., Zhang, Y., 2005. Leaf nitrogen and phosphorus stoichiometry across 753 terrestrial plant species in China. New Phytol. 168, 377-385.

Hewitt, B., 1958. Spectrophotometric determination of total carbohydrate. Nature $182,246-247$.

Hoch, G., Körner, C., 2003. The carbon charging of pines at the climatic treeline: a global comparison. Oecologia 135, 10-21.

Hoch, G., Popp, M., Körner, C., 2002. Altitudinal increase of mobile carbon pools in Pinus cembra suggests sink limitation of growth at the Swiss treeline. Oikos 98, $361-374$. 
Hoch, G., Richter, A., Körner, C., 2003. Non-structural carbon compounds in temperate forest trees. Plant Cell Environ. 26, 1067-1081.

Körner, C., 1998. A re-assessment of high elevation treeline positions and their explanation. Oecologia 115, 445-459.

Körner, C., 2003. Carbon limitation in trees. J. Ecol. 91, 4-17.

Kabeya, D., Sakai, S., 2003. The role of roots and cotyledons as storage organs in early stages of establishment in Quercus crispula: a quantitative analysis of the nonstructural carbohydrate in cotyledons and roots. Ann. Bot. 92, 537-545.

Koch, K., 1996. Carbohydrate-modulated gene expression in plants. Annu. Rev. Plant Physiol. Plant Mol. Biol. 47, 509-540.

Li, M.H., Hoch, G., Körner, C., 2001. Spatial variability of mobile carbohydrates within Pinus cembra trees at the alpine treeline. Phyton 41, 203-213.

Li, M.H., Hoch, G., Körner, C., 2002. Source/sink removal affects mobile carbohydrates in Pinus cembra at the Swiss treeline. Trees 16, 331-337.

Li, M.H., et al., 2008. Mobile carbohydrates in Himalayan treeline trees I. Evidence for carbon gain limitation but not for growth limitation. Tree Physiol. 28, 1287-1296.

Loewe, A., Einig, W., Shi, L., Dizengremel, P., Hampp, R., 2000. Mycorrhiza formation and elevated $\mathrm{CO}_{2}$ both increase the capacity for sucrose synthesis in source leaves of spruce and aspen. New Phytol. 145, 565-574.

Mooney, H., Billings, W., 1965. Effects of altitude on carbohydrate content of mountain plants. Ecology 46, 750-751.

Mooney, H.A., 1972. The carbon balance of plants. Annu. Rev. Ecol. Systemat. 3, 315-346.

Myers, J.A., Kitajima, K., 2007. Carbohydrate storage enhances seedling shade and stress tolerance in a neotropical forest. J. Ecol. 95, 383-395.

Nanamori, M., Shinano, T., Wasaki, J., Yamamura, T., Rao, I.M., Osaki, M., 2004. Low phosphorus tolerance mechanisms: phosphorus recycling and photosynthate partitioning in the tropical forage grass, Brachiaria hybrid cultivar mulato compared with rice. Plant Cell Physiol. 45, 460-469.

Newell, E.A., Mulkey, S.S., Wright, S.J., 2002. Seasonal patterns of carbohydrate storage in four tropical tree species. Oecologia 131, 333-342.

Ögren, E., 2000. Maintenance respiration correlates with sugar but not nitrogen concentration in dormant plants. Physiol. Plant. 108, 295-299.

Ogren, E., Nilsson, T., Sundblad, L.G., 1997. Relationship between respiratory depletion of sugars and loss of cold hardiness in coniferous seedlings over-wintering at raised temperatures: indications of different sensitivities of spruce and pine. Plant Cell Environ. 20, 247-253.

Palacio, S., Maestro, M., Montserrat-Martí, G., 2007. Seasonal dynamics of nonstructural carbohydrates in two species of Mediterranean sub-shrubs with different leaf phenology. Environ. Exp. Bot. 59, 34-42.

Pan, Q.M., Han, X.G., Bai, Y.F., Yang, J.C., 2002. Advances in physiology and ecology studies on stored non-structure carbohydrates in plants. Chin. Bull. Bot. 19, 30-38.

Patton, A.J., Cunningham, S.M., Volenec, J.J., Peicher, Z.J., 2007. Differences in freeze tolerance of zoysiagrasses: II. Carbohydrate and proline accumulation. Crop Sci. 47, 2170-2181.

Poorter, L., Kitajima, K., 2007. Carbohydrate storage and light requirements of tropical moist and dry forest tree species. Ecology 88, 1000-1011.

Sala, A., Woodruff, D.R., Meinzer, F.C., 2012. Carbon dynamics in trees: feast or famine? Tree Physiol. 32, 764-775.

Scartazza, A., Moscatello, S., Matteucci, G., Battistelli, A., Brugnoli, E., 2013. Seasonal and inter-annual dynamics of growth, non-structural carbohydrates and C stable isotopes in a mediterranean beech forest. Tree Physiol. 33, 730-742.

Schellenbaum, L., Sprenger, N., Schuepp, H., Wiemken, A., Boller, T., 1999. Effects of drought, transgenic expression of a fructan synthesizing enzyme and of mycorrhizal symbiosis on growth and soluble carbohydrate pools in tobacco plants. New Phytol. 142, 67-77.

Schulze, E., Mooney, H., Dunn, E., 1967. Wintertime photosynthesis of bristlecone pine (Pinus aristata) in the White Mountains of California. Ecology 48, 1044-1047.

Stevens, G.C., Fox, J.F., 1991. The causes of treeline. Annu. Rev. Ecol. Systemat. 22, 177-191.

Strand, A., Foyer, C.H., Gustafsson, P., Gardestrom, P., Hurry, V., 2003. Altering flux through the sucrose biosynthesis pathway in transgenic Arabidopsis thaliana modifies photosynthetic acclimation at low temperatures and the development of freezing tolerance. Plant Cell Environ. 26, 523-535.

Thompson, K., Parkinson, J.A., Band, S.R., Spencer, R.E., 1997. A comparative study of leaf nutrient concentrations in a regional herbaceous flora. New Phytol. 136, 679-689.

Tissue, D., Wright, S., 1995. Effect of seasonal water availability on phenology and the annual shoot carbohydrate cycle of tropical forest shrubs. Funct. Ecol. 9, 518-527.

Trethewey, R.N., Aprees, T., 1994. A mutant of Arabidopsis thaliana lacking the ability to transport glucose across the chloroplast envelope. Biochem. J. 301, 449-454.

Trom, E., Sheath, G., Bryant, A., 1989. Seasonal variations in total nonstructural carbohydrate and major element levels in perennial ryegrass and paspalum in a mixed pasture. N. Z. J. Agric. Res. 32, 157-165.

Van den Ende, W., De Roover, J., Van Laere, A., 1999. Effect of nitrogen concentration on fructan and fructan metabolizing enzymes in young chicory plants (Cichorium intybus). Physiol. Plant. 105, 2-8.

Volaire, F., Gandoin, J.M., 1996. The effect of age of the sward on the relationship between water-soluble carbohydrate accumulation and drought survival in two contrasted populations of cocksfoot (Dactylis glomerata L.). Grass Forage Sci. 51, $190-198$.

Volenec, J., Ourry, A., Joern, B., 1996. A role for nitrogen reserves in forage regrowth and stress tolerance. Physiol. Plant. 97, 185-193.

Wang, R.L., Yu, G.R., He, N.P., Wang, Q.F., Zhao, N., Xu, Z.W., Ge, J.P., 2015. Latitudinal variation of leaf stomatal traits from species to community level in forests: linkage with ecosystem productivity. Sci. Rep. 5, 14454, http://dx.doi.org/10.1038/ srep14454.

Würth, M.K., Pelaez-Riedl, S., Wright, S.J., Körner, C., 2005. Non-structural carbohydrate pools in a tropical forest. Oecologia 143, 11-24.

Wardle, P., 1993. Causes of alpine timberline: a review of the hypotheses. In: Forest Development in Cold Climates. Springer, pp. 89-103.

Wright, I.J., et al., 2004. The worldwide leaf economics spectrum. Nature 428, $821-827$.

Wright, I.J., Westoby, M., Reich, P.B., 2002. Convergence towards higher leaf mass per area in dry and nutrient-poor habitats has different consequences for leaf life span. J. Ecol. 90, 534-543.

Xu, W.D., 1985. Kira's temperature indices and their application in the study of vegetation. J. Ecol. 3, 215-222.

Yan, Z.H., Kuan, W.C., Chang, W.X., 2014. Spatial variations in non-structural carbohydrates in stems of twelve temperate tree species. Trees Struct. Funct. 28, 77-89.

Yin, J.J., Guo, D.L., He, S.Y., Zhang, L., 2009. Non-structural carbohydrate, N, and P allocation patterns of two temperature tree species in a semi-arid region of Inner Mongolia. Acta Sci. Nat. Univ. Pekin. 45, 519-527.

Zhang, H.Y., Dong, S.T., Gao, R.Z., 2006. Research progresses of starch in plants. J. Chin. Cereals Oils Assoc. 21, 41-46.

Zhang, X.S., Yang, D.A., 1995. Eastern and northern transects of China research. Quat. Sci. 15, 43-52. 